\title{
Depressive Symptoms in Medical Students and Their Association with Hormonal and Socioeconomic Variables
}

\section{Sintomas Depressivos em Estudantes de Medicina e sua Relação com Variáveis Hormonais e Socioeconômicas}

\author{
Gabriel Marcelo Rêgo de Paula ${ }^{I}(\mathbb{D})$ \\ Vanessa Izidoro Alves Silva ${ }^{I}(\mathbb{D}$ \\ Mariane Soriano Duarte Prado Tenorio ${ }^{I}$ (D) \\ Daniela Queiroz Pinto ${ }^{I}$ (iD \\ Camila Calado de Vasconcelos ${ }^{I}$ (D) \\ Ana Soraya Lima Barbosa ${ }^{I} \mathbb{D}$
}

\section{KEYWORDS}

- Depression.

- Hydrocortisone.

- Medical Students.

- Medical Education.

- Religion.

\section{ABSTRACT}

Introduction: Depression disables and compromises quality of life, so that its high prevalence in medical students is a relevant problem. It is known that hormonal variables, such as cortisolemia, as well as socioeconomic factors can be related to the onset of depressive symptoms. This study aimed to verify the prevalence of depressive symptoms in medical students at a University Center in Maceió and analyze their correlation with serum cortisol levels, lifestyle and socioeconomic profile. Method: Quantitative, analytical and cross-sectional study of medical students from a private medical school in Maceió. A sample of 122 students participated in the study, which applied the Beck Depression Inventory, socioeconomic questionnaire and serum cortisol dosage. Results: Of the 78 women and 44 men participating in the study, 40 cases of depressive symptoms were identified (32.9\%), of which 3 cases had severe depressive symptoms (2.5\%), 9 cases had moderate depressive symptoms (7.4\%) and 28 had mild depressive symptoms (23.0\%). As for the cortisol levels, the mean value obtained was $12.72 \mu \mathrm{g} / \mathrm{dL}$, with a maximum and minimum value of $29.7 \mu \mathrm{g} / \mathrm{dL}$ and $0.9 \mu \mathrm{g} / \mathrm{dL}$, respectively. No correlation was found between depressive symptoms and morning serum cortisol levels in this study. Among the explanatory variables analyzed, only religion attained a statistically significant correlation with depressive symptoms, with a prevalence of higher scores in students who did not have a religion. Conclusion: It can be emphasized that there is a high prevalence of depression among medical students. The results obtained in this study show that the hypothalamic-pituitary-adrenal axis alteration is not the only etiology associated with the development of depression. In turn, religious practice showed to be statistically significant in relation to the lowest rate of depressive symptoms, revealing itself as a probable protective factor against the development of depression. 


\section{PALAVRAS-CHAVE}

- Depressão.

- Hidrocortisona.

- Estudantes de Medicina.

- Educação Médica.

- Religião.

Received on 1/13/20.

Accepted on 8/20/20.

\section{INTRODUCTION}

Depressive disorders, together with heart disease, constitute the group of diseases with the highest prevalence and growth in the world's population, thus becoming a public health problem ${ }^{1}$. Estimates refer to more than 300 million people living with this psychological distress condition, with an increase of more than $18 \%$ between 2005 and $2015^{2,3}$. In 2020, the World Health Organization estimates that depression will reach the second place in the list of "Disability Adjusted Life Years DALYs" ranking, regardless of age and gender".

Medical students are usually affected by depression, which can have negative consequences on their academic performance and professional future ${ }^{4}$. The clinical symptoms of depression are diverse and can be permeated by depressed mood, sadness, loss of interest or pleasure, significant weight loss or gain, insomnia (initial, maintenance or terminal) or hypersomnia, agitation or psychomotor retardation, fatigue or loss of energy, feelings of uselessness or inappropriate guilt, indecision or decreased capacity to think or concentrate and recurring thoughts of death ${ }^{5}$.

A considerable number of higher education students have some type of psychiatric disorder during their training ${ }^{6}$. Studies carried out in Dubai and Estonia show a prevalence of depression in medical students of around $28.6 \%$ and $30.6 \%$, respectively ${ }^{7,8}$. In Brazil, studies in university centers in São Paulo and Goiás showed that $38.2 \%$ and $26.8 \%$ of medical students had depressive symptoms, respectively ${ }^{9,10}$.

Medical students usually do not seek medical help for their problems, constituting one of the main barriers to psychiatric care in this group? Analyses have shown that, despite the high emotional loads that this group endures, less than $20 \%$ seek to take care of their Mental Health during their training $g^{9,11}$. As a consequence, there is a high prevalence of suicide, depression, drug use, marital disorders and professional disorders ${ }^{4,911-16}$.

Some variables can justify depressive symptoms in medical students,

\section{RESUMO}

Introdução: A depressão incapacita e causa comprometimento da qualidade de vida, de modo que a alta este estudo teve como objetivos verificar a prevalência de sintomas depressivos em estudantes de Medicina de um centro universitário de Maceió e analisar sua correlação com os níveis de cortisol sérico, os hábitos de vida e o perfil socioeconômico. Método: Trata-se de estudo quantitativo, analítico e de caráter transversal com estudantes de Medicina de uma faculdade privada de Maceió. Uma amostra de 122 acadêmicos aderiu à pesquisa, na qua se aplicaram o Inventário de Depressão de Beck e um questionário socioeconômico. Realizou-se ainda a dosagem do cortisol sérico. Resultados: Dentre 78 mulheres e 44 homens participantes, foram identificados 40 casos de intomas depressivos (32,9\%), sendo três casos de sintomas depressivos graves (2,5\%), nove casos de sintomas dos (7,4\%) e 28 com sintomas depressivos leves (23,0\%). Quanto à dosagem de cortisol, respectivamente. Não foi constatada nenhuma correlação entre os sintomas depressivos e os níveis de cortisol matinal neste estudo. Entre as variáveis explicativas analisadas, apenas religião obteve uma correlação

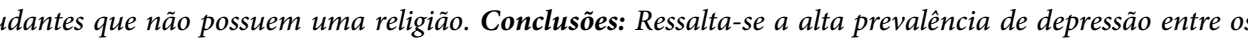
etiologia associada ao desenvolvimento da depressão. Por sua vez, a prática religiosa revelou-se como um provável fator protetor do seu desenvolvimento. 
the importance of adequate mental health monitoring of individuals with such symptoms ${ }^{10,17,27}$.

Considering the stigma created by psychiatric diseases, as well as the lack of support from the social circle itself, people with depressive symptoms are resistant to seek medical help to attain a healthier and more productive life ${ }^{3}$. Therefore, the importance of research on mental disorders is evidenced, especially for the early detection of depression in groups that live under constant stressors, such as medical students, for instance, as well as for the understanding of the pathophysiological bases in the context of the involved biopsychosocial aspects.

Therefore, the present study aimed to determine the prevalence of depression in medical students at a university center in Maceió and its correlation with serum cortisol levels, lifestyle and socioeconomic profile.

\section{MATERIALS AND METHODS}

This was a quantitative, analytical, cross-sectional study that used a questionnaire-based approach and measurement of morning serum cortisol levels. The population consisted of 320 students between the second and eighth semesters of the medical course at a University Center located in the city of Maceió, state of Alagoas, Brazil. As it is a new course at the institution, there were still no classes attending medical internship (from the ninth to the twelfth semesters). Students attending the first semester of undergraduate school were excluded from the research to avoid confusion bias, due to the possible influence of stressors related to the recent university's admission exam, in addition to having to adapt to the new study routine.

The study was approved by the Institutional Research Ethics Committee, under number CAAE 69217517.9.0000.0039, of which recorded documents contained the research information and the instruments used, with knowledge of and authorization by the course coordination.

Data collection was carried out between April and May 2018, in which participants were selected by probabilistic sampling, in a stratified random sample, totaling 122 students who accepted to participate in the study and signed the free informed consent form (ICF), of both genders, over 18 years old, without diagnosed hormonal dysfunctions and not using hormonal medications, such as hormonal supplementation or corticosteroids, since these affect the pituitary-hypothalamus-adrenal system and could compromise the results of the serum cortisol levels.

Data collection was carried out using questionnaires containing objective questions. Issues related to socioeconomic data, lifestyle and psychosocial aspects were addressed. The instruments used were: the Beck Depression Inventory (BDI), consisting of 21 groups of statements that assess the rates of depressive symptoms ${ }^{30}$; and the questionnaire to assess life habits and socioeconomic levels, consisting of 30 objective questions that address variables that may be directly associated to depression in students, such as gender; age group; time spent in extra-class study; times spent in in-class study; practice of physical activities; monitoring by health professionals; religion; leisure time; family time, among others ${ }^{31}$.

After data collection, the results of the depressive symptoms were categorized as recommended by the Beck Depression Inventory; therefore, there are four categories of symptom classification subdivided by scores: 0-13 (none or minimum); 14-19 (mild); 20-28 (moderate); 29-63 (severe) ${ }^{30}$.

The measurement of morning serum cortisol levels, which is an important stress marker and may be related to depressive symptoms, the object of this research, was performed by a specialized team from a laboratory diagnostic center, who came to the institution and, after the collection, transported and analyzed the samples using the chemiluminescence method.

After data collection, statistical analyses were performed in order to compare the quantitative and qualitative variables - serum cortisol levels; gender; age group; time spent in extra-class study; weekly course load; practice of physical activities; monitoring by health professionals; religion; leisure time; family time. The data were organized in tables and graphs after the statistical analysis.

In the inferential statistics, the presence or absence of depressive symptoms in the interviewed students was assessed using the univariate analysis of variance (one-way ANOVA), after verifying the normality and homoscedasticity of the data using the Shapiro and Levene tests, respectively ${ }^{32}$. Significant differences in the absolute frequency between the identified categories of depressive symptoms (minimal, mild, moderate and severe) were investigated using Tukey post-hoc test.

Possible influences of the life habits of the study participants (e.g., religion, hours of sleep, hours of study and consumption of alcoholic beverages) on the obtained scores of depressive symptoms and cortisol levels were analyzed using the Kruskal-Wallis test. Specifically, the categories of answers obtained for each question were considered as nominal variables ${ }^{33}$, allowing comparisons to be made between different subsets of data. In terms of inferring the meaning of the obtained results, the participants who chose not to answer a certain question were excluded from the analyses. In addition, the association between the Beck Depression Inventory scores and the students' morning serum cortisol levels was tested using simple linear regression.

All statistical analyses were performed using the free software PAST statistics $^{34}$, adopting a significance level of $5 \%(\mathrm{p}<0.05)$.

\section{RESULTS}

One hundred twenty-two Beck Depression Inventories (IDB) delivered by the research volunteers were counted. According to the cutoff points, the results were subdivided by scores of depressive symptoms into the following: 0-13 (none); 14-19 (mild); 20-28 (moderate); 29-63 or more (severe), with the distribution according to gender and classification of depressive symptoms shown in Table 1.

\section{Table 1}

Distribution by gender and score obtained at the Beck Depression

Inventory in medical students from a private institution in Maceió, 2018

\begin{tabular}{|ccccccc|}
\hline $\begin{array}{c}\text { Classification of } \\
\text { depressive symptoms }\end{array}$ & \multicolumn{2}{c}{ Male } & \multicolumn{2}{c}{ Female } & \multicolumn{2}{c|}{ Total } \\
\hline 0 to $13-$ None & 28 & 63.7 & 46 & 59.0 & 74 & 60.6 \\
\hline 14 to $19-$ Mild & 5 & 11.4 & 23 & 29.5 & 28 & 23.0 \\
\hline 20 to $28-$ Moderate & 4 & 9.0 & 5 & 6.4 & 9 & 7.4 \\
\hline 29 to $63-$ Severe & 2 & 4.5 & 1 & 1.3 & 3 & 2.5 \\
\hline DWA $^{*}$ & 5 & 11.4 & 3 & 3.8 & 8 & 6.5 \\
\hline TOTAL & 44 & 100 & 78 & 100 & 122 & 100 \\
\hline
\end{tabular}

$p>0.05$ (p: 0.30).

${ }^{\star}$ DWA $=$ Didn't want to answer

Source: Research, 2018

REVISTA BRASILEIRA DE EDUCAÇ̃̃o MÉDICA

3 44(4) : e133; 2020 
The values obtained with the Beck scale for the interviewed students ranged between 0 and 34 , with an average value of $11.21 \pm 6.89$. Research participants were characterized by the absence $(65 \%)$ or the presence of depressive symptoms of mild (24.5\%), moderate (7.9\%) and severe intensity (2.6\%) (ANOVA, F=11, 27, p <0.05, Figure 1).

The distribution of serum cortisol values of medical students participating in the research is shown in Table 2, with a mean value of $12.72 \mu \mathrm{g} / \mathrm{dL}$, with a standard deviation (SD) of 3.96, a maximum value of $29.7 \mu \mathrm{g} / \mathrm{dL}$ and a minimum value of $0.9 \mu \mathrm{g} / \mathrm{dL}$.

The mean cortisol level of students who had some depressive symptom according to the BDI was as follows: severe symptoms: $9.77 \mu \mathrm{g} / \mathrm{dL},(\mathrm{SD}=7.06)$; moderate symptoms: $12.96 \mu \mathrm{g} / \mathrm{dL}(\mathrm{SD}=4.51)$; mild depressive symptoms: $12.75 \mu \mathrm{g} / \mathrm{dL}$ ( $\mathrm{SD}=5.3$ ). Those who had minimal or nonexistent depression had a mean serum cortisol of $12.89 \mu \mathrm{gL},(\mathrm{SD}=5.54)$.

The absolute and relative percentage of the sociodemographic characteristics analyzed in the study are shown in Table 3, related to the total of 114 research participants who delivered the appropriately filled out socio-economic questionnaire forms. Of these, 13 participants (11\%) reported they had been previously diagnosed with a mental disorder, 98 (86\%) had not been diagnosed and 3 (3\%) did not want to respond. Regarding being monitored by a health professional, only 36 (32\%) said that they were. Of these, only 27 (24\%) were monitored by doctors.

As for the hours per week performing professional activity in an area outside Medicine, 21 (18\%) said they worked less than 30 hours a week, 3 (2\%) worked between 30 and 44 hours and 1 (1\%) worked more than 44 hours. Regarding instructions on mental health, 59 (52\%) stated that they had already been instructed, 43 (38\%) said they had never been instructed and $12(10 \%)$ did not inform.

Regarding how frequently they see their relatives, 95 (83\%) reported seeing their relatives at least once a week, while $18(16 \%)$ spent more than a week without seeing them. One (1\%) reported never seeing their relatives. As for the level of satisfaction with the course on a scale of 0 to 5 , with 0 being "totally dissatisfied" and 5 "fully satisfied", only $1(1 \%)$ volunteer scored 1 on the scale, 8 (7\%) scored 2, 38 ( 33\%) scored 3, 48 (42\%) scored 4 and 19 (17\%) considered themselves fully satisfied with the course, scoring 5 on the scale.

Table 4 shows the absolute and relative frequencies of the main lifestyle habits of medical students participating in the research.

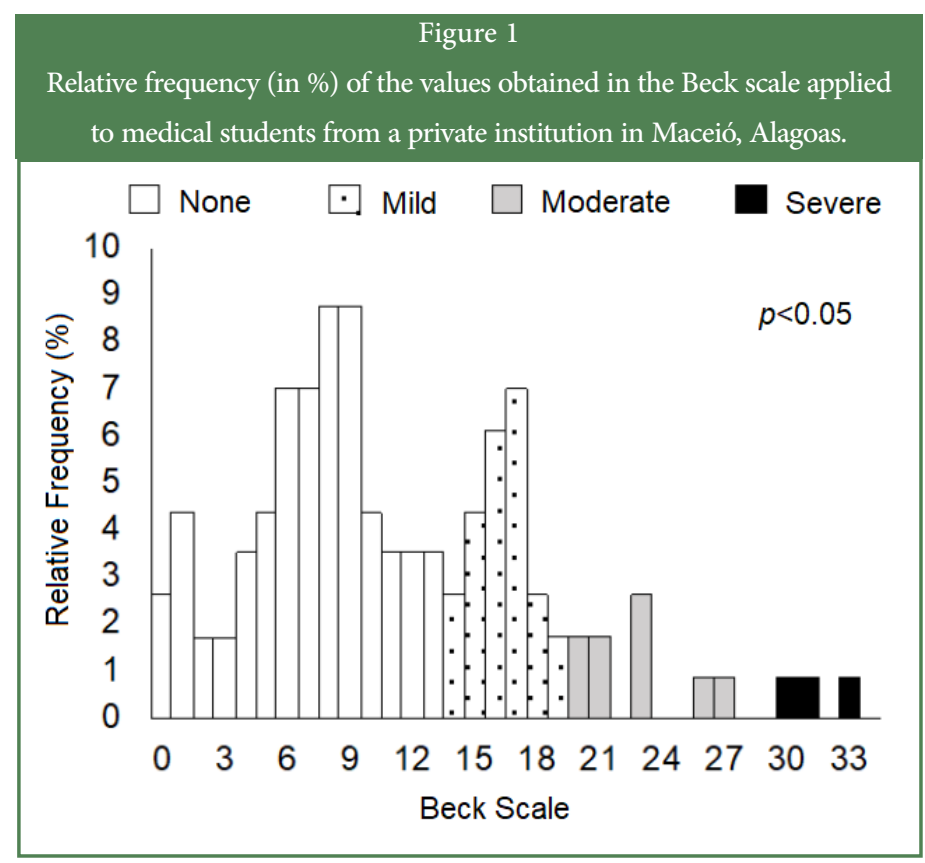

Source: Research, 2018.

\begin{tabular}{|c|c|c|}
\hline $\begin{array}{r}\text { Table } 2 \\
\text { Distribution of serum cortisol values } \\
\text { private institution in }\end{array}$ & $\begin{array}{l}\text { ical st } \\
2018\end{array}$ & rom a \\
\hline \multirow{2}{*}{ Classification of serum cortisol values } & \multicolumn{2}{|c|}{ Total } \\
\hline & $\mathbf{n}$ & $\%$ \\
\hline$<6,7 \mu \mathrm{g} / \mathrm{dL} .-$ Below the RV ${ }^{*}$ & 11 & 9.0 \\
\hline 6,7 a $22,6 \mu \mathrm{g} / \mathrm{dL}$. - Within the $\mathrm{RV}^{*}$ & 104 & 85.3 \\
\hline$>22,6 \mu \mathrm{g} / \mathrm{dL}$. - Above the $\mathrm{RV}^{*}$ & 7 & 5.7 \\
\hline TOTAL & 122 & 100 \\
\hline
\end{tabular}

${ }^{\star} \mathrm{RV}=$ Reference value by the chemiluminescence method $(6.7$ e $22.6 \mu \mathrm{g} / \mathrm{dL})$ Source: Research, 2018

\section{Table 3}

Absolute (n) and relative percentage (\%) frequencies of sociodemographic characteristics of medical students from a private institution in Maceió, 2018 Sociodemographic characteristics

n \%* $^{*}$

Gender

Male

Female

$39 \quad 34$

$75 \quad 66$ n $\%^{*}$

Ethnicity

$\begin{array}{ccc}\text { White } & 60 & 52 \\ \text { Black } & 3 & 3 \\ \text { Yellow } & 3 & 3 \\ \text { Brown } & 47 & 41 \\ \text { Indigenous } & 0 & 0 \\ \text { DWA }^{* *} & 1 & 1\end{array}$

n \%* $^{*}$

Age group

18 to 23 years

24 to 29 years

30 to 35 years

36 to 41 years

$78 \quad 69$

$27 \quad 24$ education
43

54
Incomplete Higher

n

Level of schooling

Higher education $\quad 17 \quad 15$

$97 \quad 85$ 


\begin{tabular}{|c|c|c|c|c|c|c|c|c|c|c|c|}
\hline \multicolumn{12}{|c|}{$\begin{array}{c}\text { Table } 3 \\
\text { Continuation }\end{array}$} \\
\hline \multicolumn{12}{|c|}{ Sociodemographic characteristics } \\
\hline & $\mathbf{n}$ & $\%^{*}$ & & $\mathbf{n}$ & $\%^{*}$ & & $\mathbf{n}$ & $\%^{*}$ & & $\mathbf{n}$ & $\%^{*}$ \\
\hline Professional activities & & & $\begin{array}{c}\text { Duration of professional } \\
\text { activity }\end{array}$ & & & Personal income & & & $\begin{array}{l}\text { Number of people } \\
\text { contributing to income }\end{array}$ & & \\
\hline Dentistry & 2 & 2 & No activity at the moment & 100 & 88 & No income of their own & 56 & 49 & 1 person & 25 & 22 \\
\hline Pharmacy & 2 & 2 & $<5$ years & 5 & 4 & Up to 1 minimum wage & 5 & 4 & 2 people & 76 & 67 \\
\hline Others & 10 & 9 & 6 to 15 years & 8 & 7 & 1 to 6 minimum wages & 15 & 13 & 3 people & 6 & 5 \\
\hline No professional activities & 99 & 86 & 16 to 25 years & 1 & 1 & 7 to 12 minimum wages & 1 & 1 & 4 or more people & 6 & 5 \\
\hline \multirow[t]{2}{*}{$\mathrm{DWA}^{* *}$} & 1 & 1 & & & & $>12$ minimum wages & 13 & 12 & DWA $^{* *}$ & 1 & 1 \\
\hline & & & & & & $\mathrm{DWA}^{* *}$ & 24 & 21 & & & \\
\hline Housing conditions & & & $\begin{array}{c}\text { Number of people in the } \\
\text { house }\end{array}$ & & & $\begin{array}{l}\text { Monitoring by health } \\
\text { professional }\end{array}$ & & & $\begin{array}{l}\text { Student Financing } \\
\text { Program }\end{array}$ & & \\
\hline Owns home & 75 & 66 & One & 16 & 14 & No & 78 & 68 & Yes & 32 & 28 \\
\hline Rented house & 21 & 18 & Two & 22 & 19 & Yes & 36 & 32 & No & 81 & 71 \\
\hline Student residence & 1 & 1 & Three & 28 & 24 & & & & $\mathrm{DWA}^{* *}$ & 1 & 1 \\
\hline Family home & 16 & 14 & Four & 24 & 21 & & & & & & \\
\hline \multirow[t]{2}{*}{ DWA $^{* *}$} & 1 & 1 & Five or more & 20 & 18 & & & & & & \\
\hline & & & DWA $^{* *}$ & 4 & 4 & & & & & & \\
\hline \multicolumn{12}{|l|}{ Religion } \\
\hline Catholic & 67 & 58 & & & & & & & & & \\
\hline Evangelist & 13 & 11 & & & & & & & & & \\
\hline Spiritualist & 14 & 12 & & & & & & & & & \\
\hline Jewish & 0 & 0 & & & & & & & & & \\
\hline Muslim & 0 & 0 & & & & & & & & & \\
\hline Seicho-no-Ie & 0 & 0 & & & & & & & & & \\
\hline No religion & 16 & 14 & & & & & & & & & \\
\hline Another & 2 & 1 & & & & & & & & & \\
\hline DWA $^{* *}$ & 2 & 1 & & & & & & & & & \\
\hline
\end{tabular}

${ }^{*}$ Rounded values $/{ }^{* *}$ DWA $=$ Didn't want to answer

Source: Research, 2018.

Absolute (n) and relative percentage (\%) frequencies of the life habits of medical students from a private institution in Maceió, 2018

\begin{tabular}{|c|c|c|c|c|c|c|c|c|c|c|c|}
\hline \multicolumn{12}{|c|}{ Life habits } \\
\hline & $\mathbf{N}$ & $\%^{*}$ & & $\mathbf{n}$ & $\%^{*}$ & & $\mathbf{n}$ & $\%^{*}$ & & $\mathbf{n}$ & $\%^{*}$ \\
\hline Current semester & & & $\begin{array}{c}\text { Time spent in in-class } \\
\text { study }\end{array}$ & & & $\begin{array}{l}\text { Time spent in extra- } \\
\text { class study }\end{array}$ & & & $\begin{array}{l}\text { Breaks during the study } \\
\text { period }\end{array}$ & & \\
\hline Second & 14 & 12 & $<30 \mathrm{~h}$ & 11 & 10 & $<30 \mathrm{~h}$ & 94 & 83 & Yes & 106 & 93 \\
\hline Third & 29 & 26 & 30 to $44 \mathrm{~h}$ & 89 & 78 & 30 to $44 \mathrm{~h}$ & 17 & 14 & No & 8 & 7 \\
\hline Fourth & 20 & 18 & $>44 \mathrm{~h}$ & 9 & 8 & $>44 \mathrm{~h}$ & 0 & 0 & & & \\
\hline Fifth & 14 & 12 & DWA $^{\star *}$ & 5 & 4 & $\mathrm{NDR}^{\star \star}$ & 3 & 3 & & & \\
\hline Sixth & 24 & 21 & & & & & & & & & \\
\hline Seventh & 1 & 1 & & & & & & & & & \\
\hline Eighth & 12 & 10 & & & & & & & & & \\
\hline
\end{tabular}




\begin{tabular}{|c|c|c|c|c|c|c|c|c|c|c|c|}
\hline \multicolumn{12}{|c|}{$\begin{array}{c}\text { Table } 4 \\
\text { Continuation. }\end{array}$} \\
\hline \multicolumn{12}{|c|}{ Life habits } \\
\hline & $\mathbf{N}$ & $\%^{*}$ & & $\mathbf{n}$ & $\%^{*}$ & & $\mathbf{n}$ & $\%^{*}$ & & $\mathbf{n}$ & $\%^{*}$ \\
\hline $\begin{array}{l}\text { Personal life impaired } \\
\text { by the workload }\end{array}$ & & & Hours of sleep a day & & & Weekly physical activity & & & Alcohol consumption & & \\
\hline Yes & 94 & 83 & $<6 \mathrm{~h}$ & 51 & 45 & Once & 7 & 6 & Yes & 60 & 53 \\
\hline No & 20 & 17 & 6 a $8 h$ & 63 & 55 & Twice & 22 & 19 & No & 49 & 43 \\
\hline & & & & & & 3 to 5 times & 49 & 43 & $\mathrm{DWA}^{* *}$ & 4 & 4 \\
\hline & & & & & & $>5$ times & 2 & 2 & & & \\
\hline & & & & & & Does not practice & 33 & 29 & & & \\
\hline Smoking & & & Illicit drug use & & & & & & & & \\
\hline Yes & 0 & 0 & No & 109 & 95 & & & & & & \\
\hline No & 114 & 100 & Marijuana / Hashish & 1 & 1 & & & & & & \\
\hline & & & Others & 1 & 1 & & & & & & \\
\hline & & & $\mathrm{DWA}^{\star *}$ & 3 & 3 & & & & & & \\
\hline
\end{tabular}

* Rounded numbers $/{ }^{* *}$ DWA $=$ Didn't want to answer

Source: Research, 2018.

Among the analyzed explanatory variables, only religion had a significant influence on depressive symptoms (Table 5), with a prevalence of higher scores among students who did not have a religion (Figure 2). Regarding the association between depressive symptoms and morning serum cortisol levels, no correlation was observed between the variables ( $>0.05$, Figure 3). The same was true for the other life habit variables analyzed, which did not show significant correlation with the cortisol levels of the research participants (Table 6).

\section{DISCUSSION}

Serum cortisol levels and depressive symptoms

The present cross-sectional study analyzed the association between serum cortisol levels and the presence of depressive symptoms in medical students. The prevalence of depressive symptoms in medical students found in the sample was $32.9 \%$, ranging from mild to severe. This prevalence is comparable to those found in studies carried out in Dubai and Estonia $-28.6 \%$ and $30.6 \%$, respectively ${ }^{7,8}$, as well as those observed in other Brazilian states, such as São Paulo (38.2\%) and Goiás ( $26.8 \%)^{9,10}$.

Despite the considerable prevalence of depressive symptoms in the assessed population, the serum cortisol values, in general, were within the normal range. It can be emphasized that blood collection was carried out in the middle of the school year, which may favor lower levels of cortisol when compared to periods with greater stressors, such as test periods or end of the semester.

Still, paradoxically to what the studies on the pathophysiology of depression have suggested $\mathrm{d}^{20,24,25,35,36}$ and reinforcing the controversy on the subject, the statistical analysis did not show an association between the variables cortisol levels and the presence of depressive symptoms in the analyzed population.

As a neuroendocrine response, depressive symptoms are exacerbated in the presence of a stressful event but remain exacerbated for a longer time when compared to cortisol levels ${ }^{18}$. In this sense, normal values in the collected samples do not exclude the possibility of the previous presence

\begin{tabular}{|c|c|c|}
\hline \multicolumn{3}{|c|}{$\begin{array}{l}\text { Statistical results of the influence of variables related to the lifestyle } \\
\text { habits of medical students from a private institution in Maceió on } \\
\text { depressive symptoms assessed by the Beck scale }\end{array}$} \\
\hline Variable & $\mathbf{H}\left(\mathrm{chi}^{2}\right)$ & $\mathbf{P}$ \\
\hline Gender & 1.031 & 0.30 \\
\hline Age range & 2.032 & 0.56 \\
\hline Religion & 4.266 & $0.03^{\star}$ \\
\hline Sleep duration (hours) & 1.572 & 0.20 \\
\hline In-class studies (hours) & 0.478 & 0.78 \\
\hline Extra-class studies (hours) & 2.943 & 0.08 \\
\hline Physical activity (days) & 0.792 & 0.37 \\
\hline Alcohol consumption & 0.131 & 0.71 \\
\hline
\end{tabular}

${ }^{*} \mathrm{p}<0.05$ shows statistical significance Source: Research, 2018.

of hypercortisolemia in these individuals with depressive symptoms, since this measurement was sporadic and there was no monitoring of the serum cortisol levels throughout the school semester.

Other hypotheses to be considered to explain the results found herein may be related, for instance, to the non-standardization of the laboratory analysis in the different, previously published studies, whether in relation to the type and number of samples and method; to the inability of the method to detect mild cortisol changes in individuals with depressive symptoms; or even the absence of a cut-off point established for depressive symptoms.

As a possibility to increase the sensitivity of cortisol measurement with the suspicion of depressive symptoms, in addition to the use of longitudinal studies, the literature suggests other measurement forms, 


\section{Figure 2}

Distribution of the values obtained in the Beck scale in relation to the life habits of medical students from a private institution in Maceió, Alagoas.
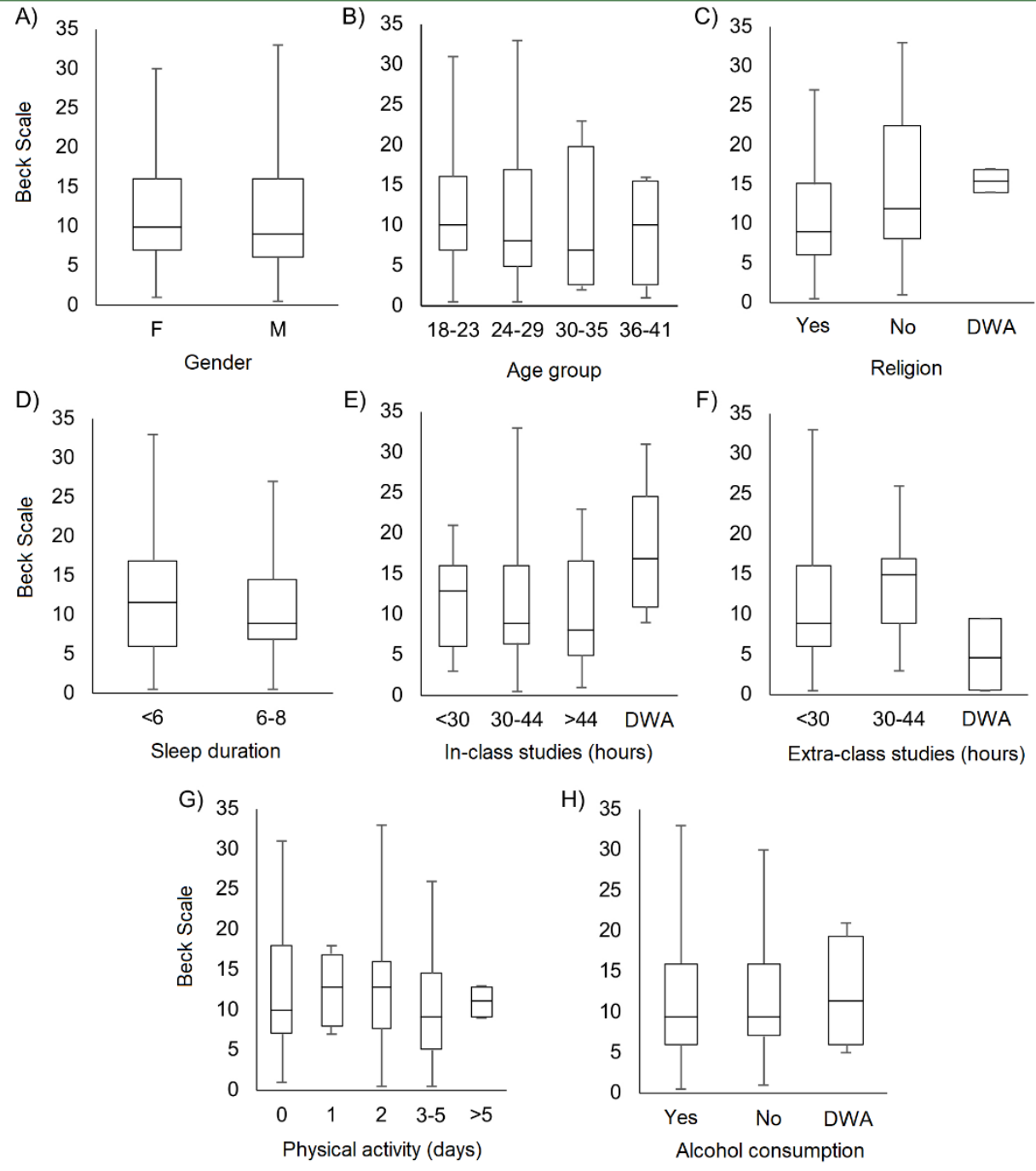

Source: Research, 2018.

\section{Figure 3}

Association between depressive symptoms (as shown by the Beck scale) and cortisol levels of medical students from a private institution in Maceió, Alagoas.

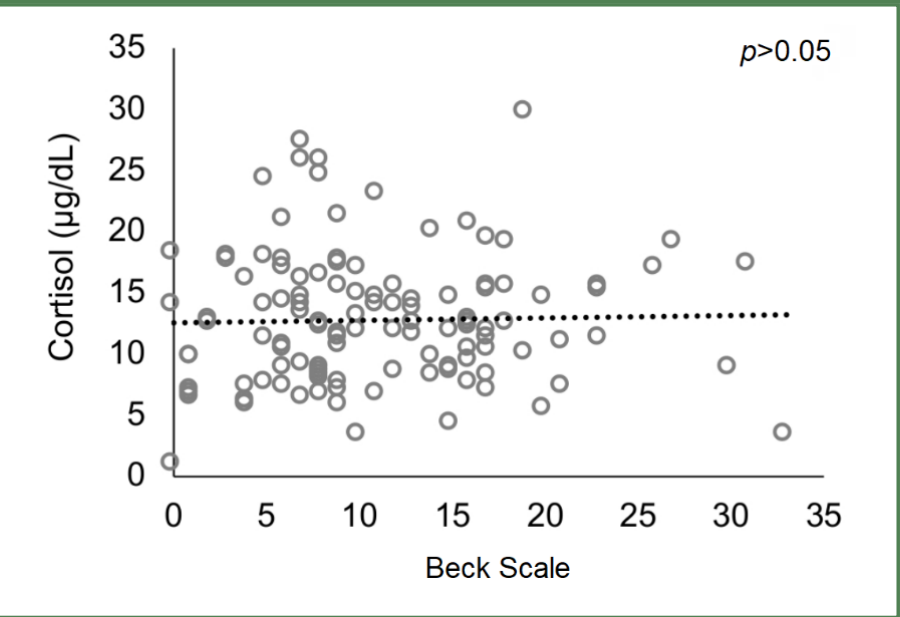

Table 6

Statistical results of the influence of the variables related to life

habits on morning serum cortisol levels of medical students from a private institution in Maceió

\begin{tabular}{|ccc} 
Variable & $\mathbf{H}\left(\mathbf{c h i}^{2}\right)$ & $\mathbf{p}$ \\
Gender & 3.136 & 0.07 \\
Age range & 5.082 & 0.16 \\
Religion & 1.146 & 0.56 \\
\hline Sleep duration (hours) & 0.012 & 0.90 \\
\hline In-class studies (hours) & 3.009 & 0.39 \\
\hline Extra-class studies (hours) & 1.503 & 0.45 \\
\hline Physical activity (days) & 0.815 & 0.36 \\
\hline Alcohol consumption & 1.135 & 0.56
\end{tabular}

Source: Research, 2018.

Source: Research, 2018. 
such as salivary, urinary, measurement from hair strands, and the previous suppression of hypothalamic-pituitary-adrenal axis with dexamethasone so the result could show greater reliability ${ }^{18,35,36}$.

The absence of a statistical correlation between the variables can also be attributed to the multifactorial origin of depressive disorders. The genotype, personality and environmental aspects can explain different types of responses to the same stressful events, so that the HPA axis is just one of the systems that contribute to the etiology of depression. In this context, the dysfunction of the HPA axis could be seen as a fundamental biological cause of major depression or, on the other hand, be a secondary phenomenon that appears in later stages ${ }^{24}$.

As cortisol is a hormone directly related to stress, the present study can be compared with the results found by Lima et al. (2016), who obtained a prevalence of $60.9 \%$ of stress symptoms in medical students from the first to the eighth semesters at a public university in the state of Paraná, through the application of the Lipp's Stress Symptom Inventory for Adults ${ }^{37}$. Other studies that used the same methodology showed similar results: $49.7 \%$ at a public university in Ceara $^{38}$ and $65.2 \%$ at a public university in Rio de Janeiro $^{39}$. Thus, even with normal cortisol levels, stress cannot be excluded as a risk factor for depression in this specific population.

\section{Socioeconomic aspects and depressive symptoms}

Regarding the social aspects involved in the development of depressive symptoms, rates 1.5 to 3 -fold higher can be seen in females. Still, they are more commonly found in people without intimate emotional ties, such as separated or divorced individuals. The male gender usually details the complaints or transfers them to other elements, such as alcohol. However, the phenomenology, the course of the disease and response to treatment are similar between the genders ${ }^{5,40}$.

The highest number of cases occurs between the $3^{\text {rd }}$ and $6^{\text {th }}$ decades of life, being three times more common in young people aged 18 to 29 years than in individuals over 60 years old $^{5,40}$. Among the economic factors considered, there is a higher prevalence of depressive symptoms in people from less favored social classes and those living in rural areas ${ }^{40}$. Despite this, in the present study, no other socioeconomic variable, except religion, was statistically significant.

Regarding religiousness, according to the World Health Organization, spiritual well-being is one of the dimensions of the health status, a fact that makes considering spirituality as one of the determinants of quality of life ${ }^{41}$. Since quality of life is seen as an integrated level of satisfaction and wellbeing, the hypothesis that religion influences the prevention of depressive symptoms is a valid one, as the present study was able to reveal a statistically significant association (p: 0.03) of how the belief in some religion is related to the prevention of the development of depressive symptoms, suggesting an inverse association between religiousness and psychiatric disorders.

Literature reports spirituality as a healthy attitude towards disease, since they consider it a way for the resignification of the meaning of life, favoring the painful acceptance and constituting a type of help that transcends itself. This transcendental experience of the psyche is similar to that stimulated with psychological therapy ${ }^{41}$, that is, it psychodynamically influences and helps the individual to deal with anxiety, fear, frustrations, anger, discouragement, among others ${ }^{42}$.

Religion also acts as a dimension that influences quality of life, a fact observed in qualitative studies that verify that people who have faith feel stronger when facing difficulties, believing in the cure of their condition. Another factor that may be related to the protective effect of religion against the development of depressive symptoms is the formation of protective behaviors, for instance, socialization and non-use of drugs, resulting in lower rates of chronic diseases and stresses ${ }^{42}$.

\section{CONCLUSION}

This study highlights the high prevalence of depression among medical students, as well as the multifactorial nature of the disease. The absence of statistical correlation between depressive symptoms and serum cortisol levels reported in the present study, to the detriment of the statistical correlation with socioeconomic variables, show that an alteration in the hypothalamic-pituitary-adrenal axis is not the only etiology associated with the development of depression. In turn, religious practice showed to be statistically significant in regard to the lowest rate of depressive symptoms, revealing itself as a probable protective factor against its development. Therefore, given the presented context, the creation and improvement of psychological support programs in Higher Education Institutions - especially in Medical Schools - are imperative, as mental health is still neglected and leads to serious consequences, both in personal life and in the future professional practice.

\section{REFERENCES}

1. Olibamoyo O, Adewuya A, Ola B, Coker O, Atilola O. Prevalence and correlates of depression among Nigerian stroke survivors. South African J Psychiatry. 2019;25:1-7.

2. Alves JGB, Tenório M, Anjos AG dos, Figueroa JN. Qualidade de vida em estudantes de Medicina no início e final do curso: avaliação pelo Whoqol-bref. Rev Bras Educ Med. 2010;34(1):91-6.

3. Organização Pan-Americana da Saúde, Organização Mundial da Saúde. Aumenta o número de pessoas com depressão no mundo. Opas, OMS; 2017. Available from: https://www.paho.org/bra/index. php?option $=$ com_content $\&$ view $=$ article $\&$ id $=5354$ : a umenta - onumero-de-pessoas-com-depressao-no-mundo\&Itemid=839. Acess on 20 oct. 2019.

4. Pacheco JPG, Giacomin HT, Tam WW, Ribeiro TB, Arab C, Bezerra IM, et al. Mental health problems among medical students in Brazil: a systematic review and meta-analysis. Rev Bras Psiquiatr. 2017;39(4):369-78.

5. Sena T. Manual diagnóstico e estatístico de transtornos mentais DSM-5, estatísticas e ciências humanas: inflexões sobre normalizações e normatizações. Revista Internacional Interdisciplinar INTERthesis. 2014;11(2):96-117].

6. Adewuya AO, Ola BA, Aloba OO, Mapayi BM, Oginni OO. Depression amongst Nigerian university students: prevalence and sociodemographic correlates. Soc Psychiatry Psychiatr Epidemiol. 2006;41(8):674-8.

7. Ahmed I, Banu H, Al-Fageer R, Al-Suwaidi R. Cognitive emotions: depression and anxiety in medical students and staff. J Crit Care. 2009;24(3):e1. doi: 10.1016/j.jcrc.2009.06.003.

8. Eller T, Aluoja A, Vasar V, Veldi M. Symptoms of anxiety and depression in Estonian medical students with sleep problems. Depress Anxiety. 2006;23(4):250-6.

9. de Vasconcelos TC, Dias BRT, Andrade LR, Melo GF, Barbosa L, Souza 
E. Prevalência de sintomas de ansiedade e depressão em estudantes de Medicina. Rev Bras Educ Med. 2015;39(1):135-42. Available from: http://www.scielo.br/scielo.php?script=sci_arttext\&pid=S010055022015000100135\&lang=pt\%0Ahttp://www.scielo.br/pdf/rbem/ v39n1/1981-5271-rbem-39-1-0135.pdf. Acess on 20 oct. 2019.

10. do Amaral GF, Gomide LMP, Batista MP, Píccolo PP, Teles TBG, de Oliveira PM, et al. Sintomas depressivos em acadêmicos de medicina da Universidade Federal de Goiás: um estudo de prevalência. Rev Psiquiatr Rio Gd Sul. 2008;30(2):124-30. Available from: http://www.scielo.br/pdf/rprs/v30n2/v30n2a08\%0Ahttp://search. ebscohost.com/login.aspx?direct=true \&db=psyh\&AN=2009-05471004\&lang=es\&site=ehost-live\%0Ahttp://gfamaral@persogo.com.br. Acess on 20 oct. 2019.

11. Richings JC, Khara GS, McDowell M. Suicide in young doctors. Br J Psychiatry. 1986;149:475-8.

12. Baldassin S, Alves TCDTF, De Andrade AG, Martins LAN. The characteristics of depressive symptoms in medical students during medical education and training: a cross-sectional study. BMC Med Educ. 2008;8:1-8.

13. Cavestro JDM, Rocha FL. Prevalência de depressão entre estudantes universitários. J Bras Psiquiatr. 2006;55(4):264-7.

14. Tabalipa FO, de Souza MF, Pfützenreuter G, Lima VC, Traebert E, Traebert J. Prevalence of anxiety and depression among medical students. Rev Bras Educ Med. 2015;39(3):388-94.

15. de Paula JDA, Borges AMFS, Bezerra LRA, Parente HV, de Paula RCA, Wajnsztejn R, et al. Prevalence and factors associated with depression in medical students. J Hum Growth Dev. 2014;24(3):274-81.

16. Ritson B. Alcohol and medical students. Med Educ. 2001;35(7):622-3.

17. Yiu V. Supporting the well-being of medical students. CMAJ. 2005;172(7):889-90.

18. Mayer SE, Lopez-Duran NL, Sen S, Abelson JL. Chronic stress, hair cortisol and depression: a prospective and longitudinal study of medical internship. Psychoneuroendocrinology. 2018;92:5765. doi: 10.1016/j.psyneuen.2018.03.020.

19. Alheira FV, Brasil MAA. The role of glucocorticoids in mood symptoms modulation: a review. Rev Psiquiatr. 2005;12(9):1-29 [access in 20 oct 2019]. Available from: http://www.ncbi.nlm.nih.gov/pubmed/810049\%0Ahttp:// doi.wiley.com/10.1002/anie.197505391\%0Ahttp://www.sciencedirect. com/science/article/pii/B9780857090409500205\%0Ahttp://www.ncbi. nlm.nih.gov/pubmed/21918515\%0Ahttp://www.cabi.org/cabebooks/ ebook/20083217094.

20. Juruena MF, Cleare AJ. Overlap between atypical depression, seasonal affective disorder and chronic fatigue syndrome. Rev Bras Psiquiatr. 2007;29(Suppl 1):19-26.

21. Juruena MF, Cleare AJ, Pariante CM. O eixo hipotálamo-pituitáriaadrenal, a função dos receptores de glicocorticóides e sua importância na depressão. Rev Bras Psiquiatr. 2004;26(3):189-201.

22. Saraiva E, Fortunato J, Gavina C. Oscilação do cortisol na depressão e sono/vigília. Rev Port Psicossomática. 2005;7(1-2):89-100 [access in 20 oct 2019]. Available from: http://www.redalyc.org/ html/287/28770207/index.html.

23. McEwen BS. Glucocorticoids, depression, and mood disorders: structural remodeling in the brain. Metabolism. 2005;54(5 Suppl):20-3.

24. Mello AF, Mello AF, Juruena MF, Juruena MF, Pariante CM, Pariante
CM, et al. Depression and stress: is there an endophenotype? Rev Bras Psiquiatr. 2007;29(Suppl I):13-8.

25. Margis R, Picon P, Cosner AFC, Silveira RO. Relação entre estressores, estresse e ansiedade. Rev Psiquiatr. 2003;25(1):65-74.

26. Joca SRL, Padovan CM, Guimarães FS. Estresse, depressão e hipocampo. Rev Bras Psiquiatr. 2003;25(Suppl 2):46-51.

27. Zonta R, Robles ACC, Grosseman S. Estratégias de enfrentamento do estresse desenvolvidas por estudantes de Medicina da Universidade Federal de Santa Catarina. Rev Bras Educ Med. 2006;30(3):147-53.

28. Meyer C, Guimarães ACA, Machado Z, Parcias SR. Qualidade de vida e estresse ocupacional em estudantes de medicina. Rev Bras Educ Med. 2012;36(4):489-98.

29. Rezende CHA, Abrão CB, Coelho EP, Passos LBS. Prevalência de sintomas depressivos entre estudantes de medicina da universidade federal de uberlandia. Rev Bras Educ Med. 2008;32(3):315-23.

30. Gomes-Oliveira MH, Gorenstein C, Neto FL, Andrade LH, Wang YP. Validação da versão brasileira em português do Inventário de Depressão de Beck-II numa amostra da comunidade. Rev Bras Psiquiatr. 2012;34(4):389-94.

31. Bassols AMS. Estresse, ansiedade, depressão, mecanismos de defesa e coping dos estudantes no início e no término do curso de medicina na Universidade Federal do Rio Grande do Sul. Porto Alegre. Tese [Doutorado]-UFRGS, 2014.

32. Caliari JS, Reinato LAF, Pio DPM, Lopes LP, Reis RK, Gir E. Quality of life of elderly people living with HIV/AIDS in outpatient follow-up. Rev Bras Enferm. 2018;71:513-22.

33. Vicente F, Espirito-Santo H, Cardoso D, da Silva F, Costa M, Martins $\mathrm{S}$, et al. Estudo longitudinal dos fatores associados à evolução de sintomas depressivos em idosos institucionalizados. J Bras Psiquiatr. 2014;63(4):308-16.

34. Hammer $\varnothing$, Harper D, Ryan P. Past: paleontological statistics software package for education and data analysis. Palaeontol Electron. 2001;4(1):1-9.

35. Meador-Woodruff JH, Greden JF, Grunhaus L, Haskett RF. Severity of depression and hypothalamic-pituitary-adrenal axis dysregulation: identification of contributing factors. Acta Psychiatr Scand. 1990;81(4):364-71.

36. Kathol G, Jaeckle S, Meller H, Lopez F. Pathofisiology of HPA axis abnormalities in pacients with major depression: an update. 1989;146 (3): 311-7.

37. de Lima RL, Soares MEC, do Prado SN, de Albuquerque GSC. Estresse do estudante de medicina e rendimento acadêmico. Rev Bras Educ Med. 2016;40(4):678-84.

38. Aguiar SM, Vieira APGF, Vieira KMF, Aguiar SM, Nóbrega JO. Prevalência de sintomas de estresse nos estudantes de medicina. J Bras Psiquiatr. 2009;58(1):34-8.

39. Furtado EDS, Falcone EMDO, Clark C. Avaliação do estresse e das habilidades sociais na experiência acadêmica de estudantes de medicina de uma universidade do Rio de Janeiro. Interação Psicol. 2003;7(2):43-51

40. Sadock BJ, Sadock VA, Ruiz P. Compêndio de psiquiatria: ciência do comportamento e psiquiatria clínica. Porto Alegre: Artmed; 2017.

41. de Miranda SL, Lanna MAL, Felippe WC. Espiritualidade, depressão e qualidade de vida no enfrentamento do câncer: estudo exploratório.

REVISTA BRASILEIRA DE EDUCAÇÃO MÉDICA

9 $94(4):$ el33; 2020 
Psicol Ciênc Prof. 2015;35(3):870-85.

42. Murakami R, Campos CJG. Religion and mental health: the challenge of integrating religiosity to patient care. Rev Bras Enferm. 2012;65(2):361-7.

\section{AUTHORS' CONTRIBUTION}

Gabriel Marcelo Rêgo de Paula contributed with the study concept, data curation, formal analysis, research and manuscript writing. Vanessa Izidoro Alves Silva contributed with the study concept, data curation, formal analysis, research and manuscript writing. Mariane Soriano Duarte Prado Tenório contributed with research, data curation and manuscript writing. Daniela Queiroz Pinto contributed with research, data curation and manuscript writing. Ana Soraya Lima Barbosa contributed with the study concept, data curation, formal analysis, methodology, supervision and manuscript writing. Camila Calado de Vasconcelos contributed with study concept, data curation, formal analysis, methodology, supervision and manuscript writing.

\section{CONFLICTS OF INTEREST}

The authors declare no conflicts of interest.

\section{ADDRESS FOR CORRESPONDENCE}

Gabriel Marcelo Rêgo de Paula. Rua Professor Luis Lavenere Machado, 383, Trapiche da Barra, Maceió, AL, Brasil. CEP: 57010-383.

E-mail: gabrielmarcelodp@gmail.com 